\title{
NONSURGICAL CLOSURE OF OROANTRAL COMMUNICATIONS USING OCCLUSAL SPLINTS
}

\author{
Oroantral Açıklıkların Okluzal Splintler ile Cerrahisiz Kapatılması
}

\author{
Nükhet KÜTÜK ${ }^{1}$, Ahmet Emin DEMİRBAŞ², \\ Canay YILMAZ ASAN ${ }^{2}$, Burcu BAŞ ${ }^{3}$, Alper ALKAN ${ }^{1}$
}

\author{
Makale Kodu/Article Code : 201578 \\ Makale Gönderilme Tarihi $\quad: 19.09 .2016$ \\ Kabul Tarihi \\ :04.03.2017
}

\begin{abstract}
Purpose: Oroantral communications (OACs) may close spontaneously, especially when the defect has a size smaller than 2-3 mm, whereas larger openings require surgical closure. The aim of this retrospective study was to present our experince with non surgical closure of small and large OACs with occlusal splints.
\end{abstract}

Materials and Methods: Clinical and radiographic data of twenty patients who had used occlusal splints after the occurance of an acute OAC were included in this study. Two groups were created according to the size of the defects: Group A: defects smaller $(<)$ than $5 \mathrm{~mm}$; and Group B: $5 \mathrm{~mm}$ and wider $(\geq)$. In all patients, a well fitted soft occlusal splint was placed for hermetic closure of the opening. All patients were followed up weekly and the splint use was stopped when complete epithelization of the OAC was observed clinically. The relationship between the size of OACs, treatment outcome, and healing time was compared statistically.

Results: OAC was healed spontaneously in all patients, except one. The healing time was found to be significantly higher in goup B than in group A. No significant difference was found between the groups with respect to the success of the treatment.

Conclusion: The use of occlusal splints seems to improve the spontaneus healing of the OACs.

Key words: Oroantral communication, occlusal splint, nonsurgical closure
ÖZ

Amaç: Defekt boyutu 2-3 mm olan oroantral açıklıklar spontan olarak iyileşebilirken büyük açıklıklarda cerrahi müdahale gereklidir. $\mathrm{Bu}$ çalışmanın amacı, küçük ve büyük oroantral açıklıkların, okluzal splintler ile cerrahisiz tedavisi hakkında bilgi sunmaktır.

Gereç ve Yöntem: Bu çalışmaya akut oroantral açıklık gelişen 12 hasta dahil edildi. Defektin boyutuna göre 2 grup oluşturuldu. Grup A: defektin $5 \mathrm{~mm}$ 'den küçük olduğu; Grup B: defektin $5 \mathrm{~mm}$ ve daha fazla olduğu hastalardan oluşmaktaydı. Bütün hastalara açıklığın kapatılması için yumuşak okluzal plak yapıldı. Hastalar haftalık olarak takip edildi ve klinik olarak tam epitelizasyon sağlandığında splint kullanımı bırakıldı. Açıklıkların boyutu ile iyileşme süresi ve tedavi sonuçları arasındaki ilişki istatistiksel olarak karşılaştırıldı.

Sonuçlar: Bir hasta dışında, tüm hastalarda oroantral açıklıklar spontan olarak iyileşti. Grup B'nin iyileşme süresinin Grup A'dan belirgin olarak fazla olduğu görüldü. Tedavinin başarısı ile ilgili gruplar arasında herhangi bir fark bulunamad.

Sonuç: Oklüzal splintlerin kullanımı, oroantral açıklıkların spontan olarak iyileşmesinde faydalı olabilir.

Anahtar Kelimeler: Oroantral açıklık, oklüzal splint, cerrahisiz kapama

\footnotetext{
${ }^{1}$ Department of Oral and Maxillofacial Surgery, Faculty of Dentistry, Bezmi Alem University, İstanbul, Turkey.

${ }^{2}$ Department of Oral and Maxillofacial Surgery, Faculty of Dentistry, Erciyes University, Kayseri, Turkey.

${ }^{3}$ Department of Oral and Maxillofacial Surgery, Faculty of Dentistry, Ondokuz Mayis University, Samsun, Turkey.
} 


\section{INTRODUCTION}

Oroantral communication (OAC) is an opening between the maxillary sinus and the oral cavity. The close relationship between the root apices of the teeth and the maxillary antrum may cause this common complication after dental extractions in the posterior maxilla. ${ }^{1}$ To prevent chronic sinusitis and the development of fistulas, it has generally been accepted that all such defects should be surgically closed within 24 to 48 hours. ${ }^{2}$ Various techniques for the closure of OACs have been proposed for the closure of oroantral fistulas, including buccal or palatal alveolar flaps and their modifications, the use of bone grafts and biomaterials. The preferred technique may vary from one clinic to another, depending on past experience. ${ }^{3}$ Although spontaneous healing may occur, especially when the size of the defect is 3 $\mathrm{mm}$ or less ${ }^{4,5}$ and sinus disease is absent or eliminated, this is not guaranteed in all cases.

The purpose of the present study was to asses the closure of acute OACs using an alternative non-surgical treatment protocol.

\section{MATERIALS AND METHODS}

This study followed the Declaration of Helsinki on medical protocol and ethics and the regional Ethical Review Board of Erciyes University approved the study. The clinical and radiographic data of the twenty acute OAC patients, treated with occlusal splint at the Department of Oral and Maxillofacial Surgery, Erciyes University Faculty of Dentistry, between 2011 and 2012, were included in this study. They were all healthy and nonsmokers. The orthopantomogram radiographes demonstrated the close proximity of the roots of the involved teeth in all cases. (Figure 1) The diagnosis of OACs were made by an experienced oral and maxillofacial surgeon with both inspection of the tooth socket and valsalva maneuver, in all patients. The size of the perforations were determined by measuring the opening with a dental curette of approximately 5 $\mathrm{mm}$ in diameter (Figure 2 and 3), and two groups were created. Group A was consisted of defects smaller $(<)$ than $5 \mathrm{~mm}$ and group B was consisted of, defects of $5 \mathrm{~mm}$ and wider $(\geq)$.

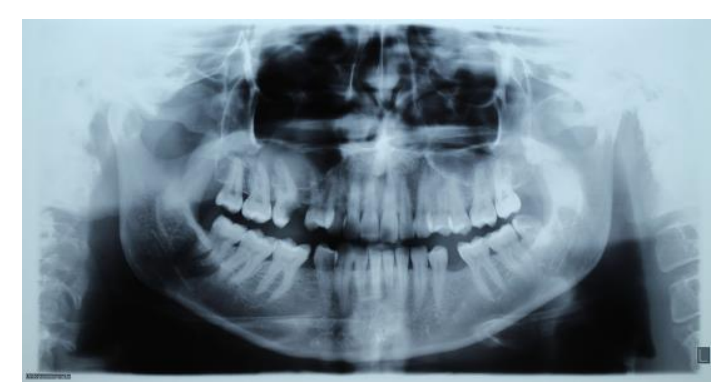

Figure 1: (Pt. 6) Close relationship between the right upper first molar and maxillary sinus

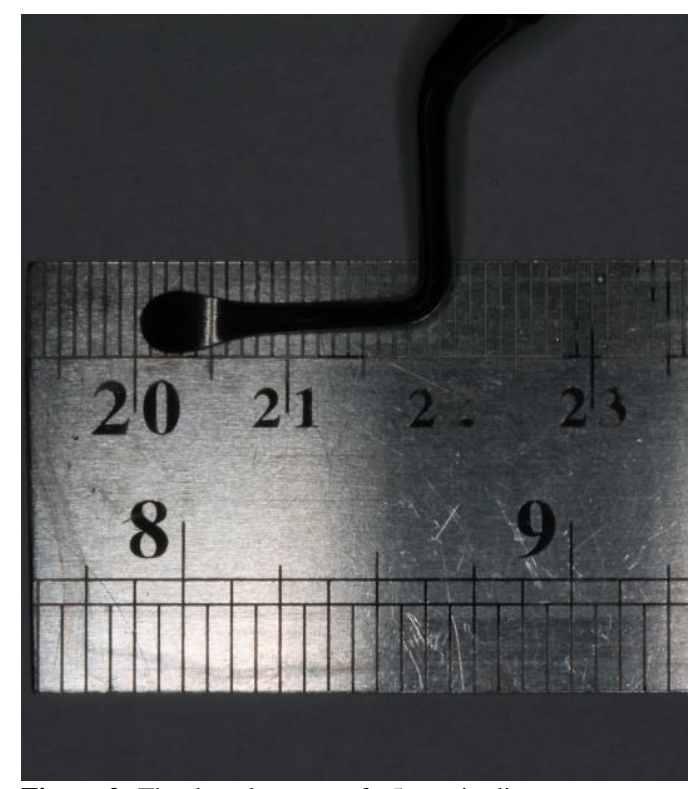

Figure 2: The dental curette of $\sim 5 \mathrm{~mm}$ in diameter

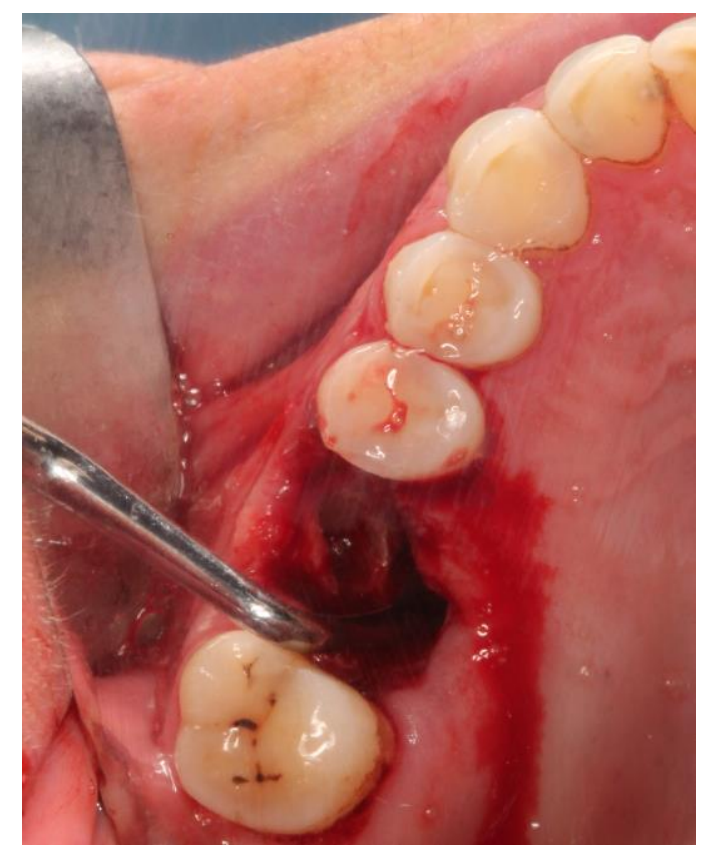

Figure 3: (Pt. 4) Measurement of an acute OAC with the dental curette 
In all patients, OACs were debrided and irrigated with saline as first line of the treatment. An oxidized cellulose hemostatic agent (SkyTeks Reoxcel ${ }^{\circledR}$, İstanbul, Turkey) was then placed into the extraction socket and a well fitted soft occlusal splint was immediately prepared and placed to the upper jaw for hermetic closure of the opening with in 24 hours (Figure 4 ).

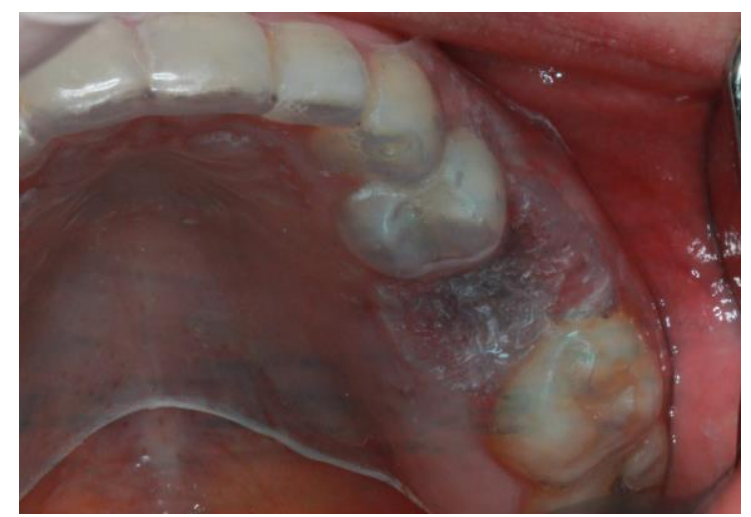

Figure 4: A soft occlusal splint in place for hermetic closure of the OAC

The fitting surface of the splint was coated with chlorhexidine gel prior to insertion. All patients were strictly instructed to wear the splint continually, removing it only after the meals at what time they rinse their mouth and the splint with clorhexidine solution. They were also advised to avoid activities which increase the intraoral or intranazal pressure such as smoking, drinking with straws, and blowing their nose. A standard postoperative medication, including amoxicillin-clavulanic acid $1 \mathrm{~g}$, twice a day, for ten days to prevent antral infection, flurbiprofen $100 \mathrm{mg}$ for pain when necessary, and clorhexidine mouth wash as long as the treatment takes, was prescribed to all patients. All patients were advised to visit our clinic for controls and irrigation of the sinus with saline solution weekly throghout the treatment time. The splint use was stopped after the epithelization completed and the healing of the OAC was observed clinically.

Data were statistically analysed with R2.14.0 programme. Mann- Whitney U test was used to evaluate the relationship between the size of OACs and healing time.

\section{RESULTS}

Of the 20 patients 11 were female $(55 \%)$ and 9 were male $(45 \%)$. The mean age of the patients were 27,05 (min: 14; max: 50). An overview of the descriptive data and treatment results were represented in Table-1. Acute OACs were occured as a complication of tooth extractions in 19 patients and, of a cyst enuclation with tooth extraction in one patient. The location of OACs was the first molar tooth in 14 patients (70\%), while it was the second molar in $4(20 \%)$, and the third molar in $2(10 \%)$ patients.

Table 1. Overview of the descriptive patient data and treatment results

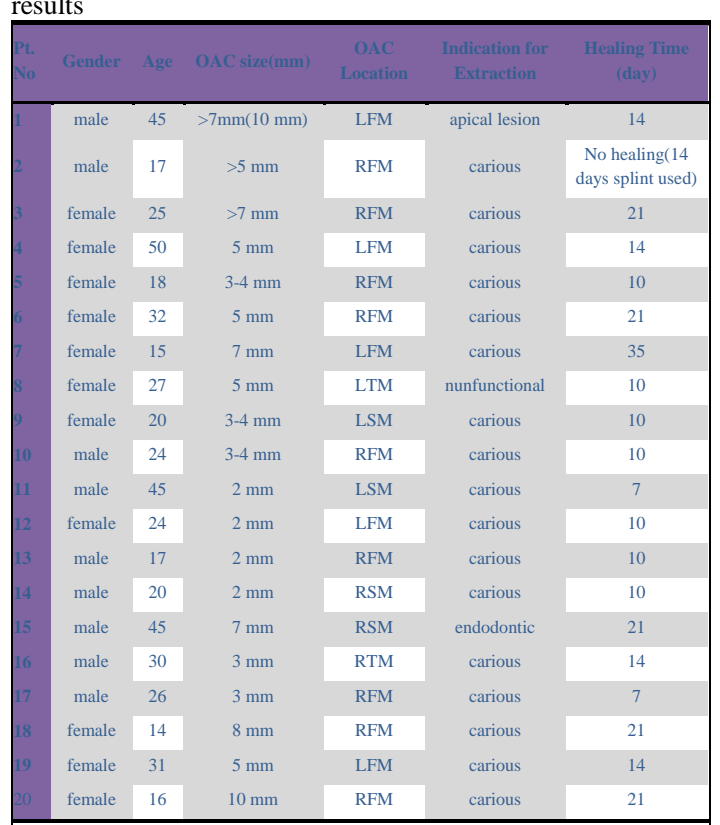

Abbervations: RFM: Right first molar; RSM: Right second molar; RTM: Right third molar LFM: Left first molar; LSM: Left second molar; LTM: Left third molar

All patients, except one, healed completely, and the OACs closed spontaneously (Figure 5-a, b; 6-a, b). Surgical closure of the OAC was performed in this patient after 35 days, and no complications were observed in the healing period. The mean healing time for the OACs was 14.7 days, ranging from 7 to 35 days. A significant difference was found between OAC size and healing time (Table 2). No complications such as sinusitis, recurrence of 
OAC, or infection occured during seven to nine months of follow-up period.

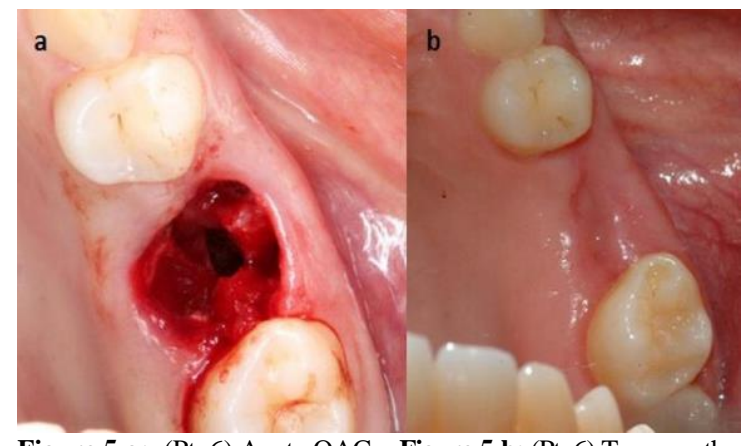

Figure 5-a: (Pt. 6) Acute OAC Figure 5-b: (Pt. 6) Two months of $\sim 5 \mathrm{~mm}$ in diameter after the extraction

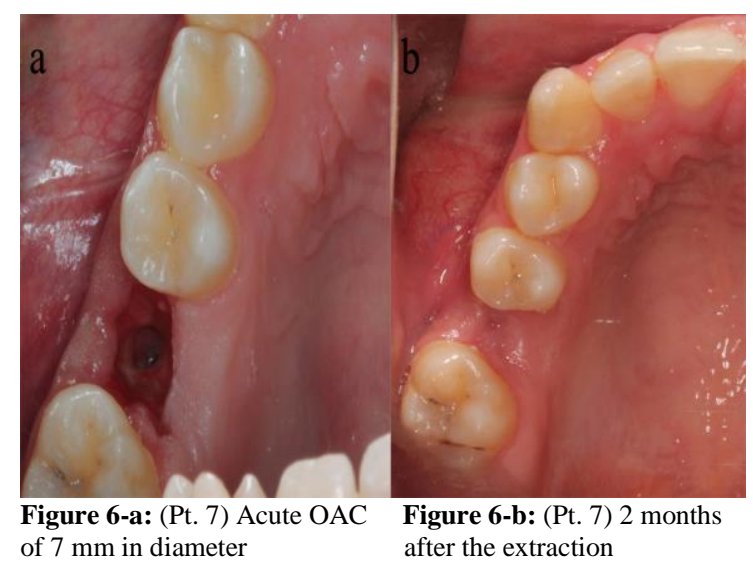

Table 2. The relation between OAC size and healing time

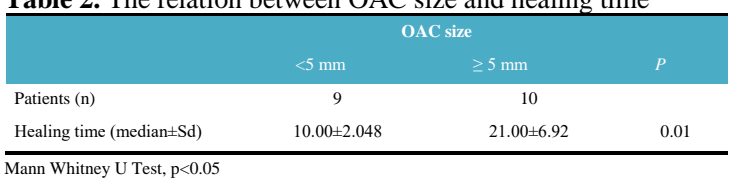

\section{DISCUSSION}

OACs are pathological entities those are often occured during or after dental treatments such as surgical extractions, removing cysts, implant surgery, trauma, tumors and pathological lesions of the maxillary sinus. ${ }^{6}$ If the opening left untreated, an oroantral fistula may develope and patients may experience sinusitis within 48 hours to 2 weeks. ${ }^{3,6,7}$ To prevent sinus infection and the development of a fistula, it has generally been recommended that these defects should be closed within 24 to 48 hours. ${ }^{2}$

Despite the simplicity and safety of most of the procedures, each surgical technique has its own drawbacks such as partial obliteration of the vestibul depht requiring a secondary vestibuloplasty when using buccal mucosal flaps ${ }^{8}$; tissue bunching and liquid passage beneath the flap ${ }^{4}$ when using palatal rotation flaps, and an increased risk of infection related to buccal fat pad flaps. Donor site morbidity is one disadvantage, which further increases postoperative pain and discomfort, depending on the surgical technique applied. The need for surgical expertise and equipment, postoperative pain and swelling are also among the various disadvantages. ${ }^{9}$ In addition, as a clinical observation, surgical options may be avoided by some patients, when they only expect a tooth extraction procedure as their physician describes the extent of a possible surgery.

Various nonsurgical techniques has been proposed in the literature. The most preferred technique is placing a gauze sponge dressing that is supported with an eight suture or acrilic splint for $48 \mathrm{~h}$, to protect the blood clot in the tooth socket. ${ }^{3}$ Resorbable hemostatic gauze composed of reconstituted oxidized cullulose was also used to maintain the blood clot in place. ${ }^{10}$ Susan et al reported a $80 \%$ successful rate with biodegradable polyurethane foam in patients with OACs with diameters up to 7 mm. ${ }^{11}$ However, good oral hygen, patient cooperation and close follow up is very important in such cases.

The maximum size of OACs that tend to heal spontaneously is controversial in the literature. Most reports agreed on that small defects of 1 to $2 \mathrm{~mm}$ heals spontaneously after the formation of a blood clot. ${ }^{3,6,12,13,14,15}$ Others contend that defects smaller than $5 \mathrm{~mm}$ may close naturally when there is no prior infection. ${ }^{2,16}$ However, it is difficult to determine the size of OACs clinically. ${ }^{17}$ In our study, we measured the OACs with a dental curette of approximately $5 \mathrm{~mm}$ in diameter, and, clasiffied them into two groups according to the defect sizes which were described either 'less than 5 $\mathrm{mm}$ ' or ' $5 \mathrm{~mm}$ or greater'. Spontaneous healing was observed at defects either less or larger than $5 \mathrm{~mm}$. No significant difference was found 
between the two groups with regard to the treatment success. However, the healing time was significantly higher in the larger defect group. These results suggest that the spontaneous regeneration of oral mucosa may be supported by the use of occlusal splints in the defects either less or larger than $5 \mathrm{~mm}$. Nevertheless, the healing period may be longer for larger defects, as in one of our cases, in which complete epitelization was observed at the 35th day. Because of the reduction of the defect size over time, and no complications associated to the maxillary sinus were observed, the splint use was continued for a long time in this patient. In one patient in group B however, no reduction of the defect size were observed during the 14 days of follow period. Therefore, the OAC was closed surgically with buccal fat pad.

Primary reason of immediate closure of the OAC is to prevent the risk of oral bacteria invading the maxillary sinus and causing maxillary infection, or in long term the development of a fistula. ${ }^{11}$ An oroantral fistula is a canal covered with epithelium which may or may not be filled with granulation tissue or polyposis of the sinus membrane. The airflow from the sinus trough the oral cavity facilitates the formation of a fistular canal. ${ }^{18}$ Sokler et al. proposed that, by permanent wearing of a palatal plate, with occasional rinsing of the sinus with a physiological solution, enteral application of an antibiotic and rinsing with a solvent antibiotic, it is possible to achive spontaneous closure of the fistula, even in cases which have existed for more than a month. ${ }^{18}$ Logan and Coates ${ }^{19}$ used this method for OACs in an immunocompromised patient, de-epithelizing the fistula and covering the OAC with an acrylic splint. They achieved complete healing after continuous use of the splint for eight weeks. In the present study, with a similar method, acute OACs healed completely, in a period of 7 to 35 days, with no complications in 6-8 months of follow up period, in healthy patients. We believe, as long as the air current, which may disrupt the blood clot, is prevented to pass through the OAC, and all the measures for sinus infection are applied, the fistula may close spontaneously.

The presented technique has in fact been used for years to support surgical flaps in oral and maxillofacial surgery. There are several advantages of using occlusal splints to treat OACs when compared to the surgical options. First, this technique is minimal invasive and can be applied immediately after tooth extraction. Second, dental practitioners can also treat OACs immediately using this method. Third, it may be more acceptable for the patients due to the decreased rate of morbidity of this procedure. The drawbacks of this method are the necessity of patient compliance, and the need for follow up appointments once a week until the OAC is completely closed.

In conclusion, immediate diagnosis and adequate treatment of OACs are very important in order to prevent the formation of an oroantral fistula, and subsequent complications. The use of an occlusal splint with systemic antibiotics, and antimicrobial mouth washes seems to be safe and predictable for the closure of OACs as a nonsurgical method in either small or large perforations of the maxillary sinus. Further prospective studies are needed which compares the treatment results of different non surgical procedures in the treatment of acute OACs.

\section{ACKNOWLEDGEMENT}

This report was presented as a poster at the 6th AÇBID International Oral and Maxillofacial Surgery Society Congress 30th of May - 3rd of June, 2012, Antalya, Türkiye

\section{CONFLICT OF INTEREST}

Authors have no conflict of interest.

\section{REFERENCES}

1. Neuschl M, Kluba S, Krimmel M, Reinert S. Iatrogenic transposition of the parotid duct into the maxillary sinus after tooth extraction and closure of an oroantral fistula. A case report. J Craniomaxillofac Surg. 2010 Oct;38(7):538-540. 
2. von Wowern $\mathrm{N}$ : Correlation between the development of an oroantral fistula and the size of the corresponding bony defect. J Oral Surg. 1973; 31(2):98-102

3. Guven O: A clinical study on oroantral fistulae. J Craniomaxillofac Surg. 1998; 26:267-271.

4. Anavi Y, Gal G, Silfen R, Calderon S. Palatal rotation-advancement flap for delayed repair of oroantral fistula: a retrospective evaluation of 63 cases. Oral Surg Oral Med Oral Pathol Oral Radiol Endod. 2003 Nov;96(5):527-534.

5. Abuabara A, Cortez AL, Passeri LA, de Moraes M, Moreira RW. Evaluation of different treatments for oroantral/oronasal communications: experience of 112 cases. Int $\mathrm{J}$ Oral Maxillofac Surg. 2006 Feb;35(2):155-158.

6. Lazow SK. Surgical management of the oroantral fistula: flap procedures. Operative Techniques in Otolaryngology-Head and Neck Surgery. 1999;10(2):148-152.

7. Ashley RE. LIII A Method of Closing AntroAlveolar Fistulae. Annals of Otology, Rhinology \& Laryngology. 1939;48(3):632-642.

8. Meirelles RC, Neves-Pinto RM. Oroantral fistula and genian mucosal flap: a review of 25 cases. Braz J Otorhinolaryngol. 2008 JanFeb;74(1):85-90.

9. Obradovic O, Todorovic L, Pesic V. Investigations of the buccal sulcus depth after the use of certain methods of oro-antral communication closure. Bull Group Int Rech Sci Stomatol Odontol. 1981 Sep;24(3):209-214. 10. Gacic B, Todorovic L, Kokovic V, Danilovic V, Stojcev-Stajcic L, Drazic R, Markovic A. The closure of oroantral communications with resorbable PLGA-coated beta-TCP root analogs, hemostatic gauze, or buccal flaps: a prospective study. Oral Surg Oral Med Oral Pathol Oral Radiol Endod. 2009 Dec;108(6):844-850

11.Visscher SH, Van Minnen B, Bos RR. Feasibility of conical biodegradable polyurethane foam for closure of oroantral communications. J Oral Maxillofac Surg. 2011 Feb;69(2):390-395.
12. Thoma K, Pajarola GF, Grätz KW, Schmidlin PR. Bioabsorbable root analogue for closure of oroantral communications after tooth extraction: a prospective case-cohort study. Oral Surg Oral Med Oral Pathol Oral Radiol Endod. 2006 May;101(5):558-564.

13. Herbert DC. Closure of a palatal fistula using a mucoperiosteal island flap. Br J Plast Surg. 1974 Oct;27(4):332-336.

14. Hanazawa $Y$, Itoh $K$, Mabashi $T$, Sato K. Closure of oroantral communications using a pedicled buccal fat pad graft. J Oral Maxillofac Surg. 1995 Jul;53(7):771-775

15.Keresztesi K. Conservative therapy of oroantral fistula. Osterr Z Stomatol. 1954 Jun;51(6):317-323.

16.van Minnen B, Stegenga B, van Leeuwen MB, van Kooten TG, Bos RR. Nonsurgical closure of oroantral communications with a biodegradable polyurethane foam: A pilot study in rabbits. J Oral Maxillofac Surg. 2007 Feb;65(2):218-222.

17.Visscher SH, van Minnen B, Bos RR. Closure of oroantral communications: a review of the literature. J Oral Maxillofac Surg. 2010 Jun;68(6):1384-1391.

18. Sokler K, Vuksan V, Lauc T. Treatment of oroantral fistula. Acta Stomat Croat. 2002; 36:135-140.

19.Logan RM, Coates EA. Non-surgical management of an oro-antral fistula in a patient with HIV infection. Aust Dent J. 2003 Dec;48(4):255-258.

\section{Correspondence Author}

Canay YILMAZ ASAN

Erciyes Üniversitesi

Diş Hekimliği Fakültesi

Ağız Diş Çene Cerrahisi AD.

38039 Kayseri/ Turkey

Tel: +90 3522076666

Fax: +90 3524380657

E-mail: dt_canayyilmaz@yahoo.com 